\title{
BLK wt Allele
}

National Cancer Institute

\section{Source}

National Cancer Institute. BLK wt Allele. NCI Thesaurus. Code C51112.

Human BLK wild-type allele is located within 8p23-p22 and is approximately $71 \mathrm{~kb}$ in length. This allele, which encodes tyrosine-protein kinase BLK protein, plays a putative role in B-cell-specific signal transduction. 